\title{
Library Web/Online Information Services to the Needs and Behavior of Students
}

\author{
Yau-ching LEUNG \\ College of Professional and Continuing Education (CPCE), \\ an affiliate of The Hong Kong Polytechnic University, \\ Hong Kong, China
}

pfleung@cpce-polyu.edu.hk

\begin{abstract}
The website of a higher education library has been proved to be one of the core technologies used by students in their studies. While providing web services, libraries may be benefited from a number of studies done on webpage design and factors influencing the likelihood of people in using web services. On the other hand, mobile technology has already ignited a revolution that the higher education library has to face. Whether a mobile version of the library website should be offered is worthy to be evaluated. Our user survey identified the information and resources that our students used often and some of their needs that were not being well addressed to. The findings of the user survey laid the excellent base of the redesign of the current library website as well as the design of a mobile version of it.
\end{abstract}

Keyword: web services, webpage design, higher education library, information quality, mobile website, user survey

\section{Introduction}

For a library serving a self-financed higher education institution, such as the College of Professional and Continuing Education (CPCE) Libraries, there have to be tangible needs to justify the provision of new initiatives. The prevailing of electronic resources makes the library collection have more electronic materials than physical items. With students' persistent demand for more electronic books, electronic materials will continue to increase. All in all, online information services become increasingly important that drives the CPCE Libraries to look into how well its online information services are in meeting the needs of the users and how the services can be improved.

Primarily, online information services are provided through the library website which is highly regarded as the services delivery platform (Bao, 2000) and the surrogate librarian-instructor

(Cockrell \& Jayne, 2002). One initia-

Material published as part of this publication, either on-line or in print, is copyrighted by the Informing Science Institute. Permission to make digital or paper copy of part or all of these works for personal or classroom use is granted without fee provided that the copies are not made or distributed for profit or commercial advantage AND that copies 1) bear this notice in full and 2) give the full citation on the first page. It is permissible to abstract these works so long as credit is given. To copy in all other cases or to republish or to post on a server or to redistribute to lists requires specific permission and payment of a fee. Contact Publisher@InformingScience.org to request redistribution permission.

tive that must be considered is the provision of a library website for mobile devices. It is generally considered that mobile revolution has dramatic impact on library services (Murray, 2010). Many academic libraries have already provided mobile web services (Bridges, Rempel, \& Griggs, 2010; Vila, Galvez, \& Campos, 2010; Wilson \& McCarthy, 2010). To the users, the possession of 
internet capable mobile devices is the pre-requisite to using mobile services; to the libraries, the users' adoption of mobile services in general is the pre-requisite to providing mobile library services.

This paper discusses and shows how the CPCE Libraries improved its online information services with respect to the behavior and needs of the users.

\section{Literature Review}

\section{Adoption of Mobile Devices and Mobile Services}

Mobile service subscribers in Hong Kong reached 12.48 million in 2010, representing a penetration rate of $178 \%$, one of the highest in the world (given that the population of Hong Kong is about seven million). Short messages (SMS) were commonly used, with each Hong Kong citizen old enough to use mobile devices on average using it more than twice daily (Office of The Telecommunications Authority, Hong Kong, May 2010; Office of The Telecommunications Authority, Hong Kong, Oct 2010).

To learn how the youths adopt and use mobile services, the Hong Kong Youth Association conducted in 2010 a phone interview with 512 youths of ages 12-34 selected through random sampling. The interview found that $78.5 \%$ of the interviewees, in particular those of older ages, possessed internet capable mobile devices (including mobile phones and laptops). On average each youth spent 3.45 hours using their mobile devices. It was also found that $65.5 \%$ of the interviewees read news on the internet, $43.0 \%$ uploaded or viewed social current affairs short videos at Youtube, and $33.6 \%$ voiced their opinions on the internet. Besides, $22.5 \%$ of them used blogs or social networking sites to keep in touch with friends and 14.1\% always used SMS to communicate with friends. Of all the interviewees, $72.3 \%$ engaged learning on the internet on various aspects, with $49.3 \%$ engaging quite frequently and $11.1 \%$ very frequently (Youth Research Centre, Hong Kong Federation of Youth Groups, 2010).

The situation of the United States is used as a comparison. Mobile Access 2010, a study of the Pew Internet \& American Life Project, reported that in the United States, nine out of ten youths of $18-29$ years old owned cell phones and $95 \%$ of them (representing $85 \%$ of this group) used text messages. Seven out of ten youths owned laptop computers. While $65 \%$ of the youths accessed the internet with their cell phones, $84 \%$ went online using either cell phones or laptops (A. Smith, 2010).

The ECAR Study of Undergraduate Students and Information Technology, on the other hand, focused on undergraduate students of the United States to see how they used information technology in daily life and their studies. In 2010,36,950 undergraduate students were surveyed (Appendix A). It was found that about two thirds of the respondents $(62.7 \%)$ owned internet capable handheld devices (including iPhone, Treo, BlackBerry, other internet capable cell phone, iPod touch, PDA, Pocket PC, etc.) and about half used the internet from their handheld devices daily. Social networking websites and text messaging were used by nine out of ten respondents $(90.4 \%$ for social networking websites and $92.3 \%$ for texting), with a median frequency of daily use for both. About three quarters of the respondents (72.9\%) used text messaging daily. Library websites and learning management systems continued to be the core technologies for their course studies. Nine out of ten respondents used the college and university library website $(94.2 \%)$ and $33.7 \%$ of them used it several times a week or more. The learning management system was also heavily used, with $90.3 \%$ of the respondents using it, $35.2 \%$ using it daily and $79.6 \%$ using it weekly or more. About a quarter of the respondents used ebooks in a course (S. Smith \& Caruso, 2010). 
The general situations of the United States and Hong Kong are equally encouraging to libraries who want to deliver online and mobile services to the youths. Individual libraries with such intention need to take further steps to inspect and evaluate their own internal situations.

\section{Information Architecture and Information Quality}

Many studies have been done on how the information architecture of the webpage affected information searching. Morville and Rosenfeld defined information architecture as

1. the structural design of shared information environments,

2. the combination of organization, labeling, search, and navigation systems within websites and intranets,

3. the art and science of shaping information products and experiences to support usability and findability,

4. an emerging discipline and community of practice focused on bringing principles of design and architecture to the digital landscape.

There are four components of the information architecture: the organization systems that govern how the information is categorized, the labeling systems that determine how the information is represented, the navigation systems that facilitate the browsing and moving through the information, and the searching systems that allow searching of the information accessible at the website (Morville \& Rosenfeld, 2007, pp. 4, 49).

How deep the information is under the menu options has impact on information searching as well. Menu content organized in two levels of depths resulted in fewer searching problems than three levels regardless of breadth, and the layout as well as the labeling of the web content played a role (Larson \& Czerwinski, 1998). The participants of the focus group study done by Crowley et al voiced similar opinions sharply. The participants had problems with library terminology or jargon in navigating the websites, and remarked the process required to find information on the library website was complex and confusing. They desired all needed information to be organized on a single page for immediate access (Crowley, Leffel, Ramirez, Hart, \& Armstrong, 2002).

Inter-relating with the information architecture, the information quality explains and determines whether people use the web services. The Technology Acceptance Model (TAM) explained the behavior of people towards their acceptance of a technology in terms of two dimensions -- Perceived Usefulness and Perceived Ease of Use (Davis, 1989). People would accept and use the technology that was perceived to be useful and that could be used easily. Heijden added the dimension Attractiveness to supplement the TAM (Heijden, 2003). Chae, Kim, Kim, and Ryu (2002) identified four dimensions of information quality in their study on mobile internet services: Connection, Content, Interaction, and Context. These four dimensions determine whether people find the service satisfactory, and in turn whether people are likely to use the service. Interaction includes navigation and how various elements are structured and presented, thus closely related to TAM's ease of use. Content correlates to TAM's usefulness. Context demands that the information needs to be relevant to the user's task at hand (Koivumaki, Ristola, \& Kesti, 2008). Connection requires a smooth, stable, and reliable connection to the mobile internet services.

The findings of these previous studies are helpful to the design of web services, whether mobile or not. 


\section{College of Professional and Continuing Education (CPCE) and CPCE Libraries}

The College of Professional and Continuing Education (CPCE) is a self-financed higher education institution which is also an affiliate of a government subsidized university, The Hong Kong Polytechnic University (PolyU). The Hong Kong Community College (HKCC) and the School of Professional Education and Executive Development (SPEED) are the two teaching arms of the CPCE. In 2010, the CPCE had a student population of about 8,500 FTEs, with $80 \%$ enrolled in the full-time Associate Degree programs, and 20\% enrolled in the full time pre-Associate Degree programs, full time Top-up Degree programs and part-time Degree programs. Disciplines covered are Business, Applied Social Sciences and Communication, Science and Technology, Tourism and Hospitality, Health Studies, and Applied and Media Arts. The ages of the students are primarily $18-25$.

Within the CPCE Libraries, there are two branches: the Hung Hom Bay (HHB) Library in the Hung Hom Bay Campus and the West Kowloon (WK) Library in the West Kowloon Campus. The history of the CPCE Libraries is only three years long, though the HKCC and the SPEED have a much longer history of around ten years. Before the establishment of the CPCE Libraries, the HKCC and the SPEED were supported and served by the PolyU library. Restricted by tight budgets, the collection of the CPCE Libraries grew to about 100,000 items within three years, $45 \%$ being physical books and audio-visual materials, and 55\% being full-text electronic materials including newspapers, journals, market reports, dissertations, ready reference publications, online video programs, online talks by leading world experts, and audio books. While the PolyU library continues to provide support, the CPCE Libraries is progressively taking over the major role in providing library services to the CPCE community.

\section{User Survey}

\section{Objectives}

The user survey (Appendix A) was conducted in March 2010 to study the students' web and mobile services usage, as well as their usage of and views on the library web/online information services through the CPCE Libraries website.

The survey was to find:

1. students' web and mobile services usage (eight questions),

2. students' preferences about webpage design and their views on the CPCE Libraries website with regard to their preferences to provide information on the performance (two questions),

3. students' usage of the navigation items at the CPCE Libraries website (one question),

4. the most desired improvement for the CPCE Libraries to make on the web/online information services (one open-ended question), and

5. the percentage of students possessing Wi-Fi capable mobile devices, the pre-requisite to using mobile services (two questions).

The ultimate aim was to enhance the CPCE Libraries website to match the needs and expectations of the users, and to determine whether a mobile version of the CPCE Libraries website should be provided. 


\section{Methodology}

At the time of the survey, the users consisted of students and staff only, with no alumni users. The user survey was available in hard copies at the service counter of the HHB Library and the WK Library for all users to pick up and respond. The online version was uploaded at the CPCE Libraries website for all users to access and respond on campus without user authentication and off campus with user authentication. Posters in key locations of the HHB and WK campuses were used to publicize the user survey. Emails were sent to all students and staff to invite them to respond to the survey, and users who visited the library during peak hours were invited by the library staff to answer the survey. The sampling was therefore neither random nor representative.

A total of 686 responses were received, of which only ten responses were from staff. Considering that ten responses are too few to be able to represent the totally 577 staff in the CPCE, and that staff and students are two groups of users who have different needs and behavior, this paper does not take into account of the ten staff responses, but is dedicated wholly to studying the needs and behavior of students. Totally 676 responses (610 in hard copies and 66 received online) were inspected and analyzed.

\section{Results and Findings}

\section{Web and Mobile Services Usage and Wi-Fi Capable Mobile Devices Possession}

\section{Core technologies for course study}

Our survey discovered that of all the respondents, 91\% used the CPCE Libraries website, with $31 \%$ using it once a week or more; $83 \%$ used the learning management system, the Moodle, with $52 \%$ using it once a week or more (Table 1). The high percentage of respondents using them proves that in the CPCE, similar to higher education institutions in the United States, the library website and the learning management system are the core technologies for students' studies.

\begin{tabular}{|l|c|c|c|c|c|c|c|}
\hline \multicolumn{7}{|c|}{ Table 1: Library Website and Learning Management System (Moodle) Usage } \\
\hline & Daily & $\begin{array}{c}\text { A few times } \\
\text { a week }\end{array}$ & $\begin{array}{c}\text { Once a } \\
\text { week }\end{array}$ & $\begin{array}{c}\text { Once 2 } \\
\text { weeks }\end{array}$ & $\begin{array}{l}\text { Once a } \\
\text { month }\end{array}$ & $\begin{array}{c}\text { Below once } \\
\text { a month }\end{array}$ & Never \\
\hline CPCE Libraries website & $4.3 \%$ & $14.1 \%$ & $12.5 \%$ & $13.5 \%$ & $20.3 \%$ & $26.7 \%$ & $8.6 \%$ \\
\hline $\begin{array}{l}\text { Learning management } \\
\text { system (Moodle) }\end{array}$ & $19.9 \%$ & $27.1 \%$ & $6.0 \%$ & $6.7 \%$ & $6.0 \%$ & $17.1 \%$ & $17.3 \%$ \\
\hline
\end{tabular}

\section{Possession of Wi-Fi capable mobile devices and mobile web browsing behavior}

Of the 676 respondents, 338 (50.0\%) possessed Wi-Fi capable mobile phones, $328(48.5 \%)$ owned Wi-Fi capable laptops, and 185 (27.4\%) had both Wi-Fi capable mobile phones and laptops. Altogether there were 483 respondents $(71.4 \%)$ who possessed either Wi-Fi capable mobile phones or Wi-Fi capable laptops. Nevertheless, not all respondents who had Wi-Fi capable mobile devices did take advantage and use the devices to do web browsing through mobile networking services. As shown in Table 2, of the respondents who had Wi-Fi capable mobile phones, $31.7 \%$ never used the web browsing feature and $14.7 \%$ used it less than once a month (or $53.6 \%$ used it once a month or more); of the respondents who had Wi-Fi capable laptops, $41.5 \%$ never 
used the feature and $14.8 \%$ used it less than once a month (or $43.7 \%$ used it once a month or more).

\begin{tabular}{|l|c|c|c|c|c|c|c|}
\hline \multicolumn{7}{|c|}{ Table 2: Web Browsing with Wi-Fi Capable Mobile Devices } \\
\hline & Daily & $\begin{array}{c}\text { A few times } \\
\text { a week }\end{array}$ & $\begin{array}{c}\text { Once a } \\
\text { week }\end{array}$ & $\begin{array}{c}\text { Once 2 } \\
\text { weeks }\end{array}$ & $\begin{array}{c}\text { Once a } \\
\text { month }\end{array}$ & $\begin{array}{c}\text { Below once } \\
\text { a month }\end{array}$ & Never \\
\hline $\begin{array}{l}\text { Respondents who had } \\
\text { Wi-Fi capable mobile } \\
\text { phones }\end{array}$ & $20.4 \%$ & $12.3 \%$ & $10.5 \%$ & $3.9 \%$ & $6.6 \%$ & $14.7 \%$ & $31.7 \%$ \\
\hline $\begin{array}{l}\text { Respondents who had } \\
\text { Wi-Fi capable laptops }\end{array}$ & $15.4 \%$ & $11.7 \%$ & $6.8 \%$ & $3.4 \%$ & $6.5 \%$ & $14.8 \%$ & $41.5 \%$ \\
\hline
\end{tabular}

In terms of all the 676 respondents, less than half (42.8\%) used mobile web browsing, with $11.6 \%$ using it daily and $31.9 \%$ using it once a month or more.

\section{Using campus Wi-Fi in library}

Since going online with Wi-Fi capable mobile devices outside the campus might incur a cost that kept the respondents from using it, their behavior of using wireless internet connection with mobile devices was further examined by asking whether they used the campus Wi-Fi in the library via their Wi-Fi capable laptops or mobile phones. Table 3 shows the results.

Of the respondents who had Wi-Fi capable mobile phones, $27.6 \%$ never used the campus Wi-Fi in the library and $9.9 \%$ used it less than once a month (or $62.5 \%$ used it once a month or more) with their mobile phones. Of the respondents who had Wi-Fi capable laptops, $28.4 \%$ never used the campus Wi-Fi in the library and $24.3 \%$ used it less than once a month (or $47.3 \%$ used it once a month or more) with their laptops. Though more respondents did use wireless internet connection when it was free, the increase was not drastic, with less than a $10 \%$ gain in respondents using it once a month or more.

\begin{tabular}{|l|c|c|c|c|c|c|c|}
\hline \multicolumn{7}{|c|}{ Table 3: Using Campus Wi-Fi in Library } \\
\hline & Daily & $\begin{array}{c}\text { A few times } \\
\text { a week }\end{array}$ & $\begin{array}{c}\text { Once a } \\
\text { week }\end{array}$ & $\begin{array}{c}\text { Once 2 } \\
\text { weeks }\end{array}$ & $\begin{array}{c}\text { Once a } \\
\text { month }\end{array}$ & $\begin{array}{c}\text { Below once } \\
\text { a month }\end{array}$ & Never \\
\hline $\begin{array}{l}\text { Respondents who had } \\
\text { Wi-Fi capable mobile } \\
\text { phones }\end{array}$ & $13.6 \%$ & $30.0 \%$ & $7.1 \%$ & $5.9 \%$ & $5.9 \%$ & $9.9 \%$ & $27.6 \%$ \\
\hline $\begin{array}{l}\text { Respondents who had } \\
\text { Wi-Fi capable laptops }\end{array}$ & $3.5 \%$ & $14.7 \%$ & $6.4 \%$ & $12.1 \%$ & $10.5 \%$ & $24.3 \%$ & $28.4 \%$ \\
\hline
\end{tabular}

In terms of all the 676 respondents, $7.62 \%$ and $35.6 \%$ used the campus Wi-Fi in the library daily and once a month or more respectively with mobile phones, and $2.2 \%$ and $27.5 \%$ used it in the library daily and once a month or more respectively with laptops.

It seems that the cost is not the determining factor of whether the respondents used wireless internet connection; rather it is whether they were used to using it via mobile devices. The comment collected by the open ended question of the survey gave another insight. Of the 154 comments 
received, 21 remarked that the campus Wi-Fi was unstable and un-reliable, and asked for improvement. Connection is one of the four quality dimensions (Chae, Kim, Kim, and Ryu, 2002). If people do not find the service satisfactory, they are unlikely to use it. The unsatisfactory performance of the campus Wi-Fi might be another factor that kept the respondents from more actively using it.

\section{Using Web 2.0 applications}

The respondents were asked how frequently they used the four common web 2.0 applications -blog, social networking site, video sharing site, and RSS feeds. The results, tabulated in Table 4, show that the respondents used social networking and video sharing sites more often than the blogs and RSS feeds. Nine out of ten respondents reported using social networking or video sharing sites, with $75.8 \%$ and $62.9 \%$ using social networking and video sharing sites respectively a few times a week or more. Only three thirds of the respondents used the blog, with $42.2 \%$ using it once a week or more. The usage of the RSS feeds was even lower, with $63.7 \%$ of the respondents using it and only $33.8 \%$ using it once a week or more.

\begin{tabular}{|l|c|c|c|c|c|c|c|}
\hline \multicolumn{7}{|c|}{ Table 4: Using Web 2.0 Applications } \\
\hline & Daily & $\begin{array}{c}\text { A few times } \\
\text { a week }\end{array}$ & $\begin{array}{c}\text { Once a } \\
\text { week }\end{array}$ & $\begin{array}{c}\text { Once 2 } \\
\text { weeks }\end{array}$ & $\begin{array}{c}\text { Once a } \\
\text { month }\end{array}$ & $\begin{array}{c}\text { Below once } \\
\text { a month }\end{array}$ & Never \\
\hline Social networking site & $47.2 \%$ & $28.6 \%$ & $6.4 \%$ & $3.6 \%$ & $4.6 \%$ & $2.8 \%$ & $6.9 \%$ \\
\hline Video sharing site & $23.6 \%$ & $39.3 \%$ & $12.2 \%$ & $7.5 \%$ & $6.2 \%$ & $4.8 \%$ & $6.5 \%$ \\
\hline Blog & $11.7 \%$ & $20.9 \%$ & $9.6 \%$ & $6.2 \%$ & $9.9 \%$ & $16.1 \%$ & $25.6 \%$ \\
\hline RSS feeds & $6.0 \%$ & $16.0 \%$ & $11.8 \%$ & $7.2 \%$ & $8.1 \%$ & $14.6 \%$ & $36.3 \%$ \\
\hline
\end{tabular}

Of these four web 2.0 applications, only RSS feeds have been adopted by the CPCE Libraries in service provision because of the affordable maintenance effort needed.

\section{Using college's email box and short messages (SMS)}

Both the college's email box and the SMS were proved to be the major communication tools used by the respondents. While nearly all of the respondents reported using them, $40.1 \%$ of them used the college's email box daily and $66.6 \%$ of them used the SMS daily (Table 5).

\begin{tabular}{|l|c|c|c|c|c|c|c|}
\hline \multicolumn{7}{|c|}{ Table 5: Using College's Email Box and Short Message (SMS) } \\
\hline & Daily & $\begin{array}{c}\text { A few times } \\
\text { a week }\end{array}$ & $\begin{array}{c}\text { Once a } \\
\text { week }\end{array}$ & $\begin{array}{c}\text { Once } 2 \\
\text { weeks }\end{array}$ & $\begin{array}{c}\text { Once a } \\
\text { month }\end{array}$ & $\begin{array}{c}\text { Below once } \\
\text { a month }\end{array}$ & Never \\
\hline College's email box & $40.12 \%$ & $30.16 \%$ & $9.66 \%$ & $7.58 \%$ & $4.01 \%$ & $5.20 \%$ & $3.27 \%$ \\
\hline $\begin{array}{l}\text { Short Message Service } \\
\text { (SMS) }\end{array}$ & $65.62 \%$ & $19.37 \%$ & $3.75 \%$ & $2.40 \%$ & $1.80 \%$ & $3.90 \%$ & $3.15 \%$ \\
\hline
\end{tabular}

With such a high percentage of respondents using them often, certainly the college's email box and the SMS are strong enough to be the major means for communicating with the students or delivering services to them where applicable. Due to cost considerations, the SMS has not been adopted by the CPCE Libraries in service provision. 
In summary, the adoption and use behavior of information and mobile technologies of the CPCE students are similar to the undergraduate students of the United States (S. Smith \& Caruso, 2010) with the exception of obviously lower usage of mobile web browsing or wireless internet connections.

\section{Preferences on Webpage Design and Performance Gap}

\section{CPCE libraries website at time of survey}

The layout and design of the CPCE Libraries website are governed by The Hong Kong Polytechnic University (PolyU) Web Design Guidelines (Appendix B). The guidelines aim at creating consistent and cohesive online branding for all PolyU websites to provide a similar "look and feel". Primarily, the guidelines share the same fundamental principles of information architecture found in previous studies which dealt with the navigation systems and ways of categorizing, labeling and presenting information to allow intuitive, easy navigation of the website and quick and easy access to the needed information (Morville and Rosenfeld, 2007, 41-191; Hollister, 2001; Huizingh, 1999; Jasek, 2004; and Moyo, 2002). The CPCE Libraries has little maneuverability on the general layout of the webpage, such as the logos, the header, the footer, the font size, and the global navigation bar. Nevertheless, local customization can still be made to the local navigation bar, the hotlinks, the organizational structure of the information, the labeling of the information, and the color and animation.

Figure 1 shows the main page of the CPCE Libraries website at the time of the survey.

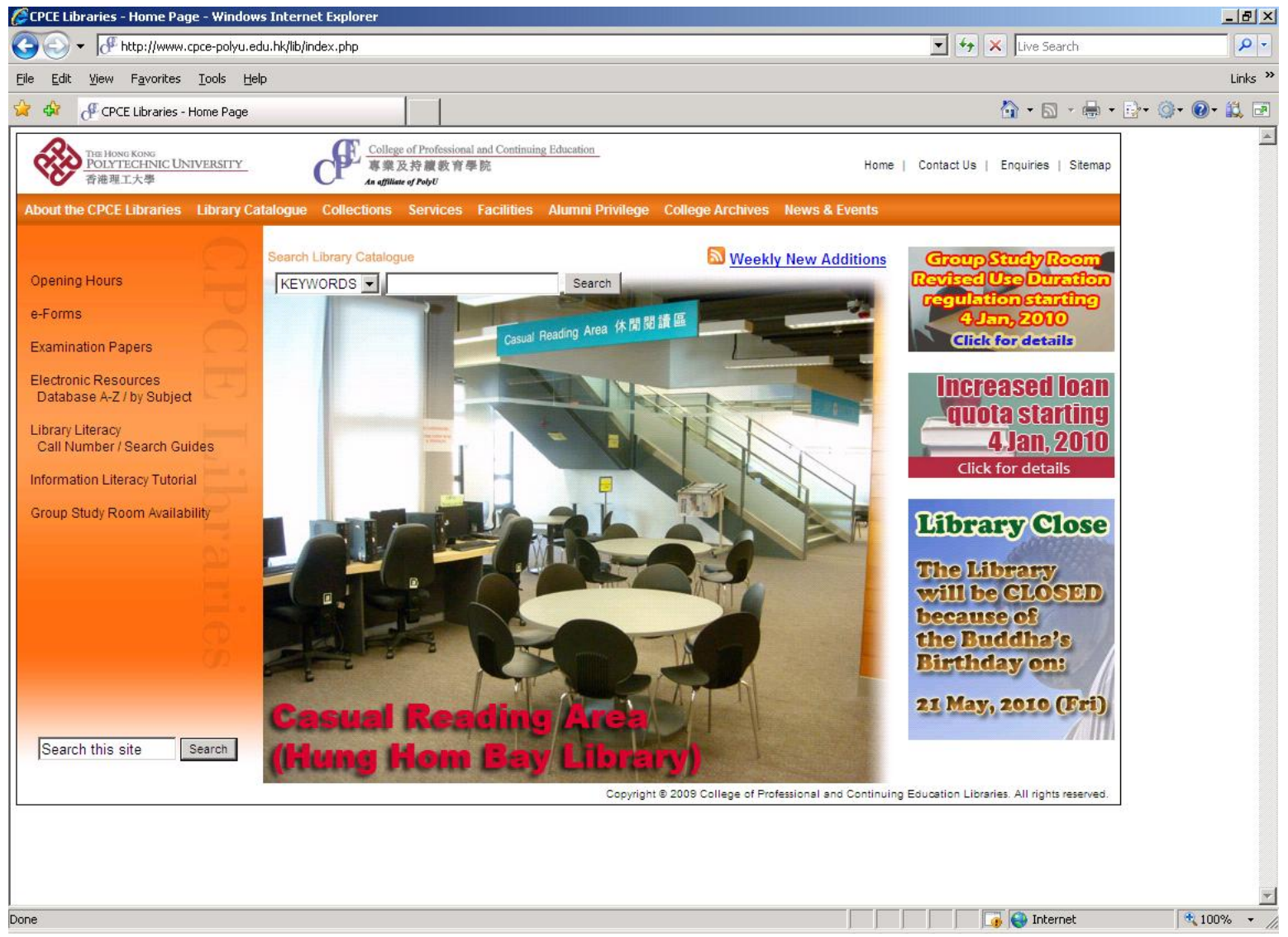

Figure 1: Main Page of CPCE Libraries Website before Revamp 
The main page had eight items on the horizontal global navigation bar. Information was organized top-down hierarchically by topics in one to three levels with the majority in two levels. There was no local navigation bar but on the vertical left seven hotlink items of which two, Electronic Resources and Library Literacy, had sub-items. The global navigation bar and the hotlinks appeared on every page of the website. The Library Catalogue search box, the Weekly New Additions, the three images on new services on the right only appeared on the main page to provide space for the display of content when an item is clicked on.

\section{Preferences and performance}

The respondents were asked to rank eight webpage design features using a 5-point scale, where 1 being the least preferred or satisfactory and 5 being the most preferred or satisfactory, to show which features were preferred and how the features were regarded, in order to establish a performance gap for improvement. The eight design features covered all the dimensions of information quality put forward by Chae et al. (2002) and Heijden (2003) except the dimension Connection, since the CPCE Libraries website was not being provided as a mobile service when the survey was conducted.

\begin{tabular}{|c|c|c|c|c|}
\hline \multicolumn{5}{|c|}{ Table 6: Webpage Design Features: User Preferences and Performance Gaps } \\
\hline Design Feature & Dimension of Quality & $\begin{array}{c}\text { Preference } \\
\text { Score }\end{array}$ & $\begin{array}{c}\text { Perception } \\
\text { Score }\end{array}$ & $\begin{array}{c}\text { Performance } \\
\text { Gap }\end{array}$ \\
\hline Ease of reaching information & Interaction (ease of use) & 4.23 & 3.35 & -0.88 \\
\hline Wordings easy to understand & Interaction (ease of use) & 4.20 & 3.46 & -0.74 \\
\hline Simple and tidy & Interaction (ease of use) & 4.03 & 3.58 & -0.45 \\
\hline Rich information & Content (usefulness) & 3.99 & 3.37 & -0.62 \\
\hline Consistent navigation bar & Interaction (ease of use) & 3.83 & 3.34 & -0.49 \\
\hline Context-sensitive instruction/help & Context or ease of use & 3.68 & 3.17 & -0.51 \\
\hline Colorful & Attractiveness & 3.67 & 3.12 & -0.55 \\
\hline Images and animations & Attractiveness & 3.41 & 2.94 & -0.47 \\
\hline & Average & 3.88 & 3.29 & -0.59 \\
\hline
\end{tabular}

The results tabulated in Table 6 show that what the respondents preferred most was not Content, but Interaction, the dimension related to the ease of use of the website. Of the eight design features being examined, the respondents ranked "Ease of reaching information", "Wordings easy to understand", and "Simple and tidy" as the top three most preferred features. The feature "Rich information", though giving the website's usefulness, was ranked as the fourth preference only. Following this was "Consistent navigation bar", again an element of Interaction which allows users to use the website easily. The two features, "Colorful" and "Images and animation", which contributed to the attractiveness or enjoyment of the website, were ranked as the bottom two preferred features. The low preference matched the previous finding that attractiveness helped to explain enjoyment better than usefulness (Heijden, 2003). Students used the library website for utilitarian use, i.e. their studies, more than for fun or enjoyment. The feature "Context-sensitive instruction/help" played a dual role. It offered information in the context of the user's task at hand (Katerattanakul and Siau, 1999; Venkatesh, 1999), and it facilitated the user in using the 
website through providing timely information in appropriate amount relevant to the user's need (Huang, Lee, and Wang, 1999).

How did the CPCE Libraries website perform? For all of the eight design features, the CPCE Libraries website failed to perform up to the preference scores. Performance gaps ranged from 0.45 to -0.87 . The best rated feature was "Simple and tidy", while the poorest rated feature was "Ease of reaching information". The second poorest rated feature was "Wordings easy to understand". The respondents did prefer more information, but they had a stronger preference for the feature that let them get what they wanted easily. In short, the respondents desired the library website to be one that they easily understood and could find the needed information easily. They did not want technical terms or jargons which were foreign to them.

Basically, however, the CPCE Libraries website succeeded in meeting the relative preferences of the respondents. Design features that were more preferred by the respondents received higher perception scores, and design features that were less preferred by the respondents received lower perception scores.

\section{Usage of Navigation Items and Hotlinks}

The menu items in the global navigation bar are supposed to allow intuitive, easy navigation of the website, as well as quick and easy access to the needed information. If they are not often used, they may not be necessary.

The survey presented a list of navigation and hotlink items and asked the respondents to tell which item(s) they used often by checking "Yes" or "No" against each item. The list included all global navigation items, but only Weekly New Additions and four of the seven hotlink items on the vertical left, i.e. Examination Papers, Electronic Resources, Library Literacy, and Group Study Room Availability. The reasons for the inclusion of some hotlink items and not others were not to overload the respondents with too many questions, and not to put those items that politically had to be at the main page to the test. Items excluded because of the second reason were Opening Hours, Information Literacy Tutorial, and e-forms which was mainly for teachers' convenience to send in recommendations on library materials and reserve materials. Table 7 shows the items in descending order of the percentage of respondents checking "Yes".

\begin{tabular}{|l|r|c|}
\hline \multicolumn{3}{|c|}{ Table 7: Global Navigation Items and Hotlinks Usage } \\
\hline \multicolumn{1}{|c|}{ Yes } & No \\
\hline Examination Papers (hotlink) & $82.71 \%$ & $17.29 \%$ \\
\hline Library Catalogue & $56.17 \%$ & $43.83 \%$ \\
\hline Electronic Resources (hotlink) & $55.32 \%$ & $44.68 \%$ \\
\hline Services & $53.09 \%$ & $46.91 \%$ \\
\hline Facilities & $51.20 \%$ & $48.80 \%$ \\
\hline Collections & $51.22 \%$ & $48.78 \%$ \\
\hline Group Study Room Availability (hotlink) & $39.36 \%$ & $60.64 \%$ \\
\hline News and Events & $33.89 \%$ & $66.11 \%$ \\
\hline About the CPCE Libraries & $35.40 \%$ & $64.60 \%$ \\
\hline College Archives & $17.40 \%$ & $82.60 \%$ \\
\hline Library Literacy (hotlink) & $17.75 \%$ & $82.25 \%$ \\
\hline Weekly New Additions (hotlink) & $12.92 \%$ & $87.08 \%$ \\
\hline Alumni Privilege & $9.68 \%$ & $90.32 \%$ \\
\hline
\end{tabular}


Eight out of ten respondents often used Examination Papers, the essential resource providing the past examination papers for preparing their examinations. Following "Examination Papers" were Library Catalogue, Electronic Resources, Services, Facilities and Collections with over half of the respondents using them often. One third of the respondents used Group Study Room Availability, News and Events, and About the CPCE Libraries often. The items with the least respondents claimed using often were College Archives, Library Literacy, Weekly New Additions (less than $20 \%$ of the respondents), and Alumni Privilege (less than $10 \%$ of the respondents).

The CPCE Libraries website adopted the common practice of multiple access points to the same information item. Examination Papers could be accessed via the hotlink on the vertical left as well as a contextual link of the global navigation item College Archives. It is interesting that respondents who claimed using College Archives often were three times fewer than the hotlink Examination Papers (17.40\% vs. $82.71 \%$ ). Similarly, though the newspapers resource could be accessed as a contextual link of the two hotlinks Electronic Resources--Database A-Z and Electronic Resources--by Subject, or the third level item of the global navigation item Collections, more than one comment collected by the open ended question requested placing it in a more prominent position so that it could be accessed more directly and easily. Obviously, the respondents desired to have all those resources that they frequently used put together in one place which was easily visualized and found, able to be reached easily and directly. Hotlinks on the main page are the most ideal and desired arrangement.

\section{Areas of Improvement}

The open ended question asked the respondents to suggest one improvement that they most desired the CPCE Libraries to make on the web/online information services. Totally 154 comments were received. Only 56 comments $(36.4 \%)$ related to the web/online information services provided through the library website, with the rest on other aspects, such as the collection, the study places, the printing and photocopying facilities, etc., which might support the study activities of the students but were beyond the scope of the survey.

Of the 56 comments on the web/online information services, 7 (13\%) gave compliments and 14 ( $25 \%)$ stated "no comment". If no comment is considered to be a positive, $38 \%$ of these 56 comments (or $13.6 \%$ of all the 154 comments) found the CPCE Libraries' web/online information services to be good, good enough, very good, or no need to change. There were 21 comments asking for faster, more stable and reliable connection of the campus Wi-Fi, which helped explain the relatively low usage rate of it by the respondents in the library.

Below are other major comments on the web/online information services, most of which asked for improvement on the dimension Interaction for higher ease of use:

1. Clear instructions for placing books on hold.

2. Add images or audio to instruction resources.

3. Concise and short instruction, not want to spend too much time searching information.

4. Clear and concise instruction for going online with laptop.

5. Clearer and more understandable interface.

6. Context-sensitive instruction/help.

7. Enhancement to improve ease of use.

8. Much more user-friendly.

9. More promotion and publicity.

10. Putting WiseNews in a more prominent position.

11. Putting all links to items that are frequently used together in one place. 
12. Adding online teaching and study resources.

13. Designing a neat webpage for mobile phone.

14. Multi-language options.

The comments further confirmed that our respondents desired to have all those items they frequently used put together in one prominent place for their easy and direct access, a desire shared by the participants of the focus group study by Crowley et al (Crowley, Leffel, Ramirez, Hart, and Armstrong, 2002).

\section{Follow-Up and Actions}

\section{Provision of Mobile Library Services}

Given the limited resources and the political environment that the CPCE Libraries was subject to, it was decided that

1. a mobile version of the CPCE Libraries website would be created. The decision was supported by the high percentage of respondents possessing internet capable mobile devices as well as their extensive use of information and mobile technologies in general. The decision was also facilitated politically by the concerted move of The Hong Kong Polytechnic University and the CPCE to revamp all unit websites in compliance with The Hong Kong Polytechnic University Web Design Guidelines. The findings of the survey laid the excellent base for the redesign.

2. a mobile library catalogue would not be provided due to the high start-up cost and the recurrent cost.

3. the college's email box would continue to be used as a major tool to communicate with students.

4. the feasibility of providing services through SMS would be looked into with prudent consideration on the cost and effort required versus the benefits.

5. though social networking and video sharing sites were better means to reach the students, the adoption of them in service provision required prudent consideration of the input needed versus the benefits, since the effort required would be much more than the RSS feeds.

\section{Re-organizing and Strengthening of the CPCE Libraries Website}

Based on the results of the survey, the information accessible at the CPCE Libraries website was re-organized and strengthened in August 2010.

\section{Interaction (ease of use)}

1. The navigation items and hotlinks were relabeled wherever appropriate to make them more self-explanatory and understandable to laypersons. The library jargon, library literacy, was abandoned.

2. Frequently used items and desired items pointed out by the respondents were put together as hotlinks on the vertical left.

3. Infrequently used items - College Archives and Alumni Privilege - were moved to deeper level of the menu content to become second level items. The information previously under Library Literacy was put under How to..., a new global navigation item with a label more self-explanatory to the users. Weekly New Additions was relocated to the main page of the library catalogue. 
4. Supported by more than half of the respondents using it often, Electronic Resources was moved up a level to become a global navigation item, while a hotlink to it remained on the vertical left. The move was also in response to the increasing subscriptions of electronic resources so as to facilitate users in accessing them.

5. Rated by the respondents as the best performed feature, the simple and tidy layout of the CPCE Libraries website was upheld.

6. Multiple access points of the same information item continued to be maintained.

7. Information continued to be organized in no more than three levels with the majority in two levels.

\section{Context}

8. Slide shows providing help and instruction for services were added to the webpage where users used the service or carried out the specific tasks. One example is the slide show on illustrating step by step how a user can assign himself/herself the Personal Identification Number (PIN) for accessing his/her patron record at the library catalogue. The slide show was added at the webpage prompting the PIN.

9. Location of Collections was added as a new hotlink while remaining a second level item under the global navigation item About the CPCE Libraries. Location of Collections serves dual purposes. It lets users know where a collection is located, and it provides contextual links to the details of the various collections that was previously grouped under the global navigation item Collections. The arrangement provides information in a better context of the user's task at hand.

10. Images linking to HKCC, SPEED, and CPCE Moodle, the learning management system, were added to the right of the header, a logical position in relation to the parent CPCE and the grandparent The Hong Kong Polytechnic University. These images on the one hand facilitate the students in navigating around their study environment and resources, on the other hand virtually put the library in a much better context of the community it serves.

\section{Attractiveness}

11. Color and animation, the least preferred features of the respondents, were kept at the current level.

\section{Others}

12. Multiple language options, basically English, Traditional Chinese, and Simplified Chinese, were not going to be offered due to the huger maintenance effort required.

The main page of the CPCE Libraries website after the reorganization and strengthening has seven global navigation items and six hotlinks of which Electronic Resources has five sub-items (Figure 2). The six hotlinks include those items specifically pointed out in the open ended question by the respondents, such as Newspapers and Wi-Fi Connection Setup. 


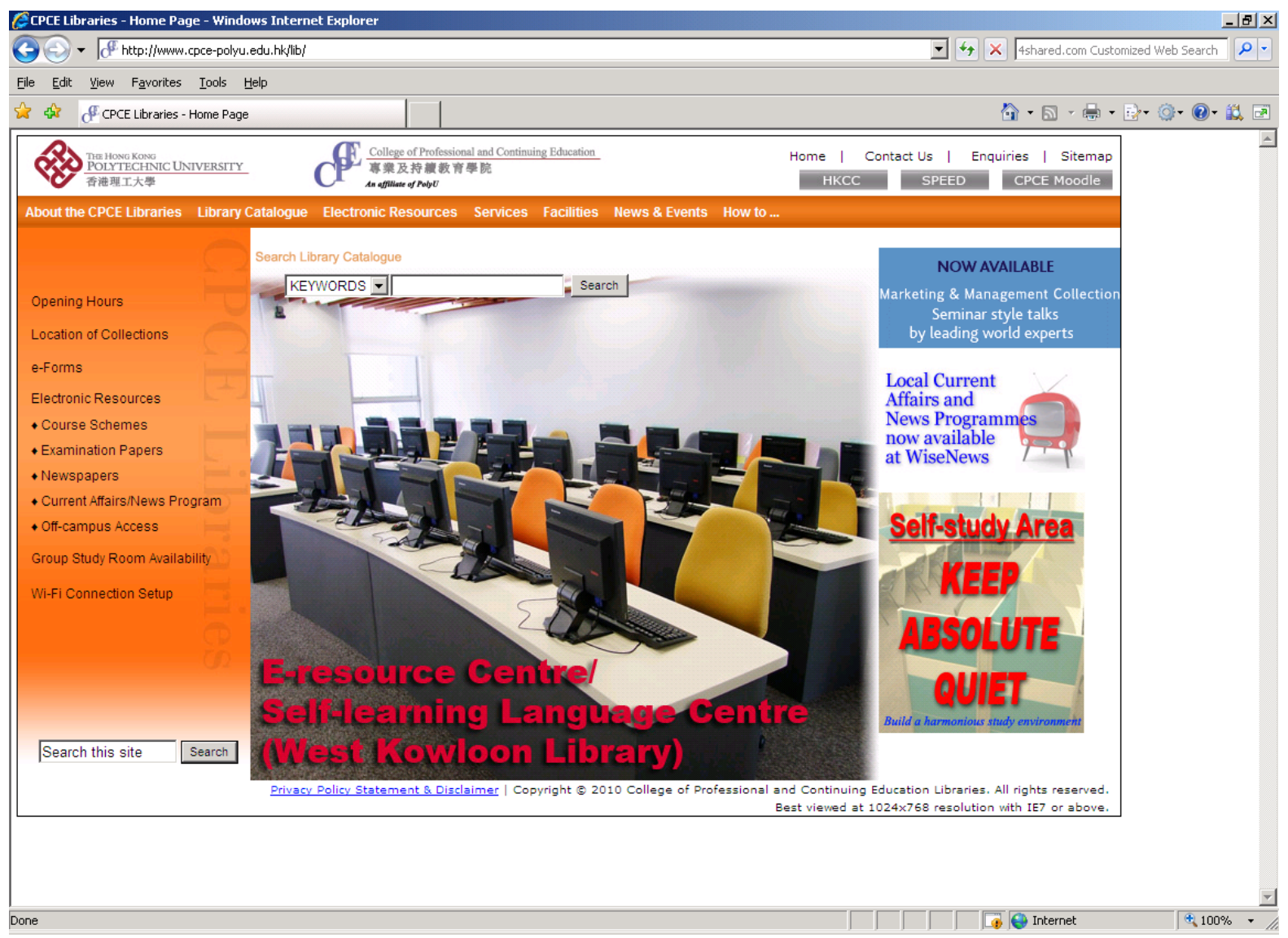

Figure 2: Main Page of CPCE Libraries Website after Revamp

The redesign does not end there. The usage statistics of the revamped website are now being tracked by the software phpMyVisites for future review and evaluation.

\section{Limitations}

The responses to the questions on the preferences, perceptions, and use behavior of the webpage exhibited not many differences between users who had Wi-Fi capable mobile devices and who did not. Apparently, the adoption of mobile technology had little effect on what the respondents preferred and how they perceived and used the website. Truly little effort was spent checking whether there was any statistical correlation between them. The reason was the nature of the survey was practical rather than theoretical, looking for practical solutions to meet the immediate needs of the students who in general only stayed with the CPCE for two years. Similarly, the sampling of the survey was neither random nor representative, which might affect the statistical significance of the findings.

The reliability of the campus Wi-Fi definitely had an effect on how active the students used it and their likelihood of using wireless internet connection. Nevertheless, it was hard for the CPCE Libraries to examine further. The campus Wi-Fi was provided and maintained by the Information Technology Unit (ITU) of the CPCE. The CPCE Libraries was aware that the ITU knew of the deficiencies of the campus Wi-Fi and was working to bring improvements, but the details of the reliability and the improvement made were not known to the CPCE Libraries.

Lastly, not all of the comments could be answered, particularly those beyond the capacity of the CPCE Libraries. One example is the link to the CPCE Libraries on the main pages of the HKCC 
and the SPEED. More than one respondent asked to have the link at a more prominent position of the main pages of the HKCC and SPEED. Whereas the link to the CPCE Libraries is at the bottom of the HKCC's main page, there is no link at the SPEED's main page. The comment was communicated to the HKCC and the SPEED, since it was them who administer their own websites. Unfortunately, both decided to keep status quo for their own reasons. Another example is the mobile library catalogue. For the political reason mentioned earlier the senior management would not object to the provision of a mobile version of the CPCE Libraries website but did not support the idea of offering a mobile library catalogue because of financial consideration. Any initiatives that, to the knowledge of the CPCE Libraries, may serve the users better are subject to the political and financial consideration of the parent institution.

\section{Conclusion}

Similar to the undergraduate students of the United States, the CPCE students highly adopted information and mobile technologies and used the library website heavily for their studies. Our survey found that our students emphasized interaction (ease of use) more than content or attractiveness in using the library web services, and desired to have those items they frequently used put together in one prominent place for immediate access. Though the CPCE Libraries website failed to perform up to the preference scores for all the eight design features examined, basically it succeeded in meeting the relative preferences of the students, and it is encouraging that more than one third of the comments related to the library website considered it good.

With reference to what were revealed in local and previous studies, the CPCE Libraries website was revamped to meet the needs and behavior of the users. On the other hand, driven by mobile technology, a library website will no longer be enough to serve the users soon in the near future, if not now. The provision of an effective mobile version of the website that can cater for common mobile devices is equally necessary when the users are widely using mobile devices and mobile services.

Review and usability study of the website from time to time are inevitable to catch up with the preferences and behavior of the users combined with the ever advancing information and communication technology, and within the political and financial context of the parent institution of the library.

\section{References}

Bao, X. M. (2000). Academic library home pages: Link location and database provision. The Journal of Academic Librarianship, 26(3), 191-195.

Bridges, L., Rempel, H. G., \& Griggs, K. (2010). Making the case for a fully mobile library web site: From floor maps to the catalog. Reference Services Review, 38(2), 309-320.

Chae, M., Kim, J., Kim, H., \& Ryu, H. (2002). Information quality for mobile internet services: A theoretical model with empirical validation. Electronic Markets, 12, 38-46.

Cockrell, B. J., \& Jayne, E. A. (2002). How do I find an article? Insights from a web usability study. The Journal of Academic Librarianship, 28(3), 122-132.

Crowley, G. H., Leffel, R., Ramirez, D., Hart, J. L., \& Armstrong, T. S., II. (2002). User perceptions of the library's web pages: A focus group study at Texas A\&M University. The Journal of Academic Librarianship, 28(4), 205-210.

Davis, F. D. (1989). Perceived usefulness, perceived ease of use, and user acceptance of information technology. MIS Quarterly, 13, 319-340.

Heijden, H. (2003). Factors influencing the usage of websites: The case of a generic portal in The Netherlands. Information \& Management, 40, 541-549. 
Hollister, C. (2001, May). The fundamentals for creating an academic library web sites. Ex Libris, 100.

Huang, K., Lee, Y. W., \& Wang, R. Y. (1999). Quality information and technology. Upper Saddle River, NJ: Prentice Hall.

Huizingh, E. (2000). The content and design of web sites: An empirical study. Information and Management, 37, 123-134.

Jasek, C. (2004). How to design library web sites to maximize usability. Library Connect, 1-16.

Katerattanakul, P., \& Siau, K. (1999). Measuring information quality of web sites: Development of an instrument. Proceedings of the $20^{\text {th }}$ International Conference on Information Systems (ICIS-99). 279285.

Koivumaki, T., Ristola, A., \& Kesti, M. (2008). The effects of information quality of mobile information services on user satisfaction and service acceptance - Empirical evidence from Finland. Behaviour \& Information Technology, 27(5), 375-385.

Larson, K., \& Czerwinski (1998). Web page design: Implications of memory, structure and scent from information retrieval. Proceedings of the Association for Computing Machinery's Computer Human Interaction Conference, 18-23.

Morville, P., \& Rosenfeld, L. (2007). Information architecture for the World Wide Web (3rd ed.). Sebastopol, CA: O'Reilly.

Moyo, L. M. (2002). Collection on the web: Some access and navigation issues. Library Collections, Acquisitions, \& Technical Services, 26(1), 47-59.

Murray, L. (2010). Libraries "like to move it, move it". Reference Services Review, 38(2), 233-249.

Office of the Telecommunications Authority, Hong Kong. (2010 May). Hong Kong: The facts. Accessed 22 November 2010 from http://www.gov.hk/en/about/abouthk/factsheets/docs/telecommunications.pdf

Office of the Telecommunications Authority, Hong Kong (2010 Oct). Key statistics for telecommunications in Hong Kong: Wireless services. Accessed 8 November 2010 from http://www.ofta.gov.hk/en/datastat/eng_wireless.pdf

Smith, A. (2010). Mobile access 2010. Pew Internet \& American Life Project. Accessed 8 November 2010 from http://www.pewinternet.org/ /media//Files/Reports/2010/PIP_Mobile_Access_2010.pdf

Smith, S., \& Caruso, J. B. (2010). The ECAR study of undergraduate students and information technology, 2010. Boulder, CO: EDUCAUSE Center for Applied Research. Accessed 8 November 2010 from http://net.educause.edu/ir/library/pdf/ERS1006/RS/ERS1006W.pdf

Venkatesh, V. (1999). Creation of favorable user perceptions: Exploring the role of intrinsic motivation. MIS Quarterly, 23, 239-260.

Vila, M. C., Galvez, A. P., \& Campos, J. C. (2010). Mobile services in the Rector Gabriel Ferrate Library, Technical University of California. Reference Services Review, 38(2), 321-334.

Wilson, S., \& McCarthy, G. (2010). The mobile university: From the library to the campus. Reference Services Review, 38(2), 214-232.

Youth Research Centre, Hong Kong Federation of Youth Groups (2010). 香港青年的數碼流動生活. Accessed 8 November 2010 from http://yrc.hkfyg.org.hk/chi/p200.html 


\section{Appendix A}

\section{CPCE Libraries User Survey: Web \& Online Information Services}

\section{Part I My Web and Mobile Applications Usages}

\begin{tabular}{|c|c|c|c|c|c|c|c|}
\hline & Daily & $\begin{array}{c}\text { A few times } \\
\text { a week }\end{array}$ & $\begin{array}{c}\text { Once } \\
\text { a week }\end{array}$ & $\begin{array}{c}\text { Once } \\
2 \text { weeks }\end{array}$ & $\begin{array}{l}\text { Once a } \\
\text { month }\end{array}$ & $\begin{array}{c}\text { Below once } \\
\text { a month }\end{array}$ & Never \\
\hline $\begin{array}{l}\text { Q1 I use Wi-Fi in the CPCE Libraries via mobile phone on } \\
\text { average }\end{array}$ & O & O & ○ & ○ & ○ & O & ○ \\
\hline $\begin{array}{l}\text { Q2 I use Wi-Fi in the CPCE Libraries via laptop computer } \\
\text { on average }\end{array}$ & ○ & O & ○ & O & ○ & ○ & ○ \\
\hline Q3 I visit the CPCE Libraries' website on average & ○ & o & ○ & ० & o & ० & ० \\
\hline Q4 I use the College's email box on average & o & ○ & O & O & O & O & O \\
\hline Q5 I use the College's E-learning system on average & ○ & ○ & ० & ○ & ○ & ○ & ○ \\
\hline \multicolumn{8}{|l|}{ Q6 I use the following Web 2.0 applications on average: } \\
\hline a. blog & ○ & ○ & ० & ○ & ○ & ○ & 0 \\
\hline b. social networking site (e.g. Face book/Twitter) & ○ & ○ & 0 & 0 & ○ & 0 & 0 \\
\hline c. video sharing site (e.g. Youtube/Youku) & ○ & ○ & ○ & ○ & ○ & ○ & ○ \\
\hline d. RSS feeds & 0 & 0 & O & O & 0 & 0 & 0 \\
\hline Q7 I use SMS (Short Messages) on average & O & ○ & ○ & o & 0 & 0 & 0 \\
\hline $\begin{array}{l}\text { Q8 I use } 3 \mathrm{G} \text { or mobile networking service for web brows- } \\
\text { ing on average }\end{array}$ & O & 0 & O & O & O & 0 & O \\
\hline
\end{tabular}

\section{Part II My Preferences and Views on Webpage Design}

Least preferred Most preferred

\begin{tabular}{|l|c|c|c|c|c|}
\hline Q9 My preferences on webpage design are & $\mathbf{1}$ & $\mathbf{2}$ & $\mathbf{3}$ & $\mathbf{4}$ & $\mathbf{5}$ \\
\hline a. Rich in information & $\circ$ & $\circ$ & $\circ$ & $\circ$ & $\circ$ \\
\hline b. Easy to reach the information that I want & $\circ$ & $\circ$ & $\circ$ & $\circ$ & $\circ$ \\
\hline c. Wordings easy to understand & $\circ$ & $\circ$ & $\circ$ & $\circ$ & $\circ$ \\
\hline d. Consistent navigation bar on every page & $\circ$ & $\circ$ & $\circ$ & $\circ$ & $\circ$ \\
\hline e. Simple and tidy & $\circ$ & $\circ$ & $\circ$ & $\circ$ & $\circ$ \\
\hline f. Colorful & $\circ$ & $\circ$ & $\circ$ & $\circ$ & $\circ$ \\
\hline g. Lots of images and animations & $\circ$ & $\circ$ & $\circ$ & $\circ$ & $\circ$ \\
\hline h. Context-sensitive instruction/help & $\circ$ & $\circ$ & $\circ$ & $\circ$ & $\circ$ \\
\hline
\end{tabular}


Least satisfactory Most satisfactory

\begin{tabular}{|c|c|c|c|c|c|}
\hline Q10 My views on the current CPCE Libraries websites design are & 1 & 2 & 3 & 4 & 5 \\
\hline a. Rich in information & 0 & 0 & 0 & 0 & 0 \\
\hline b. Easy to reach the information that I want & O & 0 & 0 & 0 & 0 \\
\hline c. Wordings easy to understand & 0 & 0 & 0 & 0 & 0 \\
\hline d. Consistent navigation bar on every page & 0 & 0 & 0 & 0 & 0 \\
\hline e. Simple and tidy & O & O & 0 & O & O \\
\hline f. Colorful & 0 & 0 & 0 & 0 & 0 \\
\hline g. Lots of images and animations & 0 & 0 & 0 & 0 & 0 \\
\hline h. Context-sensitive instruction/help & 0 & 0 & 0 & 0 & 0 \\
\hline
\end{tabular}

\section{Part III My Usages on CPCE Libraries Website}

\begin{tabular}{|l|c|c|}
\multicolumn{1}{l|}{} & Yes & No \\
\hline Q11 The following is(are) the CPCE Libraries website item(s) that I often used & & \\
\hline a. About the CPCE Libraries & 0 & 0 \\
\hline b. Library Catalogue & 0 & 0 \\
\hline c. Collections & 0 & 0 \\
\hline d. Services & 0 & 0 \\
\hline e. Facilities & 0 & 0 \\
\hline f. Alumni Privilege & 0 & \\
\hline g. College Archives & 0 & \\
\hline h. News and Events & 0 & \\
\hline i. Weekly New Additions & 0 & \\
\hline j. Examination Papers & 0 & \\
\hline k. Electronic Resources & 0 & 0 \\
\hline l. Library Literacy & 0 & $\circ$ \\
\hline m. Group Study Room Availability & 0 & 0 \\
\hline
\end{tabular}

Q12 One improvement that I most desire the CPCE Libraries to make on the web/online information services is

\section{Part IV My Personal Particulars}
Q13 I am a
○ 1. Student
- 2. Staff
Q14 My School/College is
- 1. HKCC
○ 2. SPEED
Q15 My activities are mainly at
- 1. Hunghom Bay (HHB) Campus
2. West Kolwoon (WK) Campus
Q16 I have a mobile phone with Wi-Fi capability $\circ$ 1. Yes $\circ$ 2. No
Q17 I have a laptop computer with Wi-Fi capability $\circ$ 1. Yes $\circ 2$. No 


\section{Appendix B}

\section{The Hong Kong Polytechnic University Web Design Guidelines}

Main Page

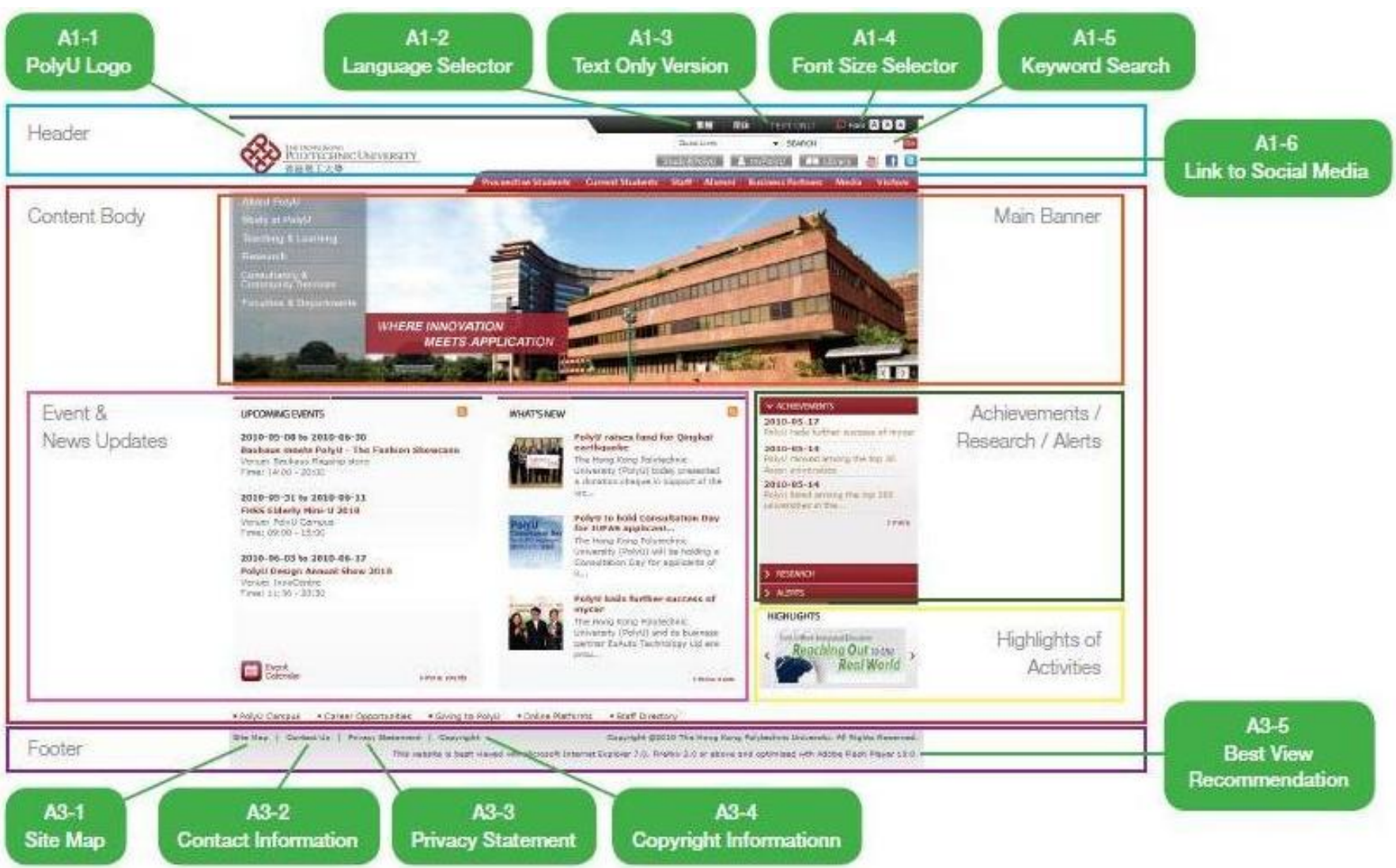

Main Page Elements

\begin{tabular}{|l|l|l|}
\hline Header & Content Body & Footer \\
\hline A1-1 PolyU logo & Main Banner & A3-1 Site map \\
\hline A1-2 Language selector & Event \& News Updates & A3-2 Contact information \\
\hline A1-3 Text only version & Achievements/Research/Alerts & A3-3 Privacy statement \\
\hline A1-4 Font size selector & Highlights of Activities & A3-4 Copyright information \\
\hline A1-5 Keyword search & & A3-5 Best view recommendation \\
\hline A1-6 Link to social media & & \\
\hline
\end{tabular}

For consistency sake, the same Header and Footer should be carried on every single page of the website. 


\section{Biography}

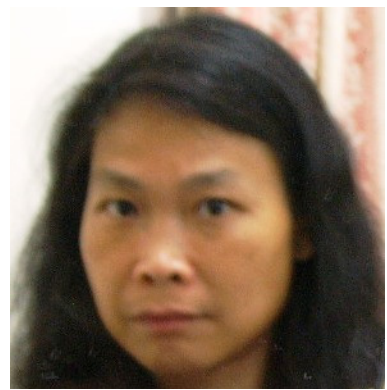

Ms Leung Yau Ching has been serving the academic libraries for nearly 20 years. Currently she is the College Librarian, College of Professional and Continuing Education (CPCE), an affiliate of The Hong Kong Polytechnic University. Prior to the current position, Ms Leung served at the University Library System, The Chinese University of Hong Kong for 15 years as the Interlibrary Loan Librarian, Reference Librarian, Circulation Librarian, and Acquisitions Librarian.

Obtaining her Master of Library Science (MLS) at the School of Library and Information Science, Indiana University at Bloomington, USA, Ms Leung was trained to be a library manager and Chemical Information Specialist. Besides publishing books, journal articles and conference papers, Ms Leung sits on the editorial boards of peer-reviewed library journals and international conferences. She is one of the pioneers who introduced internet to the Hong Kong society about 15 years ago. 